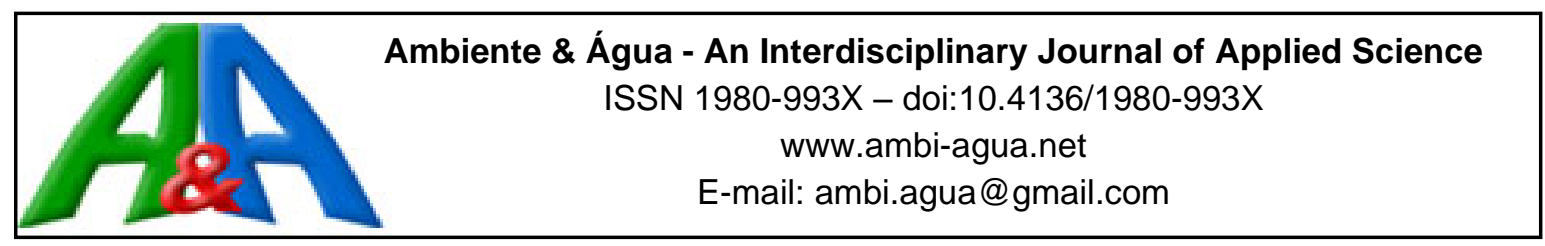

\title{
A predictive growth model for Yarrowia lipolytica ATCC 9773 in wastewater
}

ARTICLES doi:10.4136/ambi-agua.2629

Received: 01 Aug. 2020; Accepted: 17 Nov. 2020

\section{Arnulfo Antonio Tarón Dunoyer ${ }^{*}{ }^{*}$; Rafael Emilio González Cuello1 ${ }^{1 D}$; Fredy Colpas Castillo 2 it}

\author{
${ }^{1}$ Faculty of Engineering, Food Engineering Program. University of Cartagena, Street 30, $\mathrm{n}^{\circ}$ 48-152, 130014, \\ Zaragocilla, Cartagena, Colombia. E-mail: rgonzalezc1@unicartagena.edu.co \\ ${ }^{2}$ Exact and Natural Sciences Faculty. Chemistry program. University of Cartagena, Street 50, n 24120, 130014, \\ Zaragocilla, Cartagena, Colombia. E-mail: fcolpasc1@unicartagena.edu.co \\ *Corresponding author. E-mail: atarond@unicartagena.edu.co
}

\begin{abstract}
This study focuses on the development of a secondary model for Yarrowia lipolytica in a sewage treatment process. The raw data of $Y$. lipolytica growth were adjusted to the Buchanan model in order to obtain growth parameters such as initial count cells $\left(\mathrm{Y}_{0}\right)$, maximum specific growth rate $\left(\mu_{\max }\right)$, latency phase $(\lambda)$ and maximum cell population $\left(\mathrm{Y}_{\max }\right)$. The $\mu$ values obtained at different $\mathrm{pH}$ levels (5.0 to 8.0) were used to build the secondary model based on a linear equation. The results showed a significant effect of $\mathrm{pH}$ on $\mu_{\max }$ values. The validation process of the developed models displays accuracy (Af) and bias factor (Bf) values close to one, while the values of root mean square error (RMSE) were low, confirming that such models can predict the growth of Y. lipolytica in dairy wastewater. This can be interesting to optimize sewage treatments that involve this kind of microorganism. Moreover, the dairy wastewater was a good substrate to support the Yarrowia lipolytica's growth and could be used to produce enzymes.
\end{abstract}

Keywords: biological treatment, predictive microbiology, removal, wastewater, Yarrowia lipolytica.

\section{Modelo preditivo para o crescimento de Yarrowia lipolytica ATCC 9773 em um processo de biodegradação}

\section{RESUMO}

Este estudo tem como foco o desenvolvimento de um modelo secundário para Yarrowia lipolytica em processos de tratamento de esgoto. Os dados brutos de crescimento de $Y$. lipolytica foram ajustados ao modelo de Buchanan a fim de obter parâmetros de crescimento como: contagem inicial de células (Y0), taxa de crescimento específico máximo ( $\mu$ max), fase de latência $(\lambda)$ e população máxima de células (Ymax). Os valores $\mu$ obtidos em diferentes níveis de $\mathrm{pH}(5,0$ a 8,0) foram usados para construir o modelo secundário baseado em uma equação linear. Os resultados mostraram um efeito significativo do $\mathrm{pH}$ nos valores de $\mu$ max. O processo de validação dos modelos desenvolvidos apresenta valores de acurácia (Af) e fator de bias (Bf) próximos a um, enquanto os valores de root mean square error (RMSE) foram baixos, confirmando que tais modelos podem prever o crescimento de Y. lipolytica em águas residuais de laticínios. Isso pode ser interessante para otimizar tratamentos de esgoto que envolvem esse 
tipo de microrganismo. Além disso, as águas residuais do leite eram um bom substrato para apoiar o crescimento da Yarrowia lipolytica e poderiam ser utilizadas para produzir a produção de enzimas.

Palavras-chave: águas residuais, microbiologia preditiva, remoção, tratamento biológico, Yarrowia lipolytica.

\section{INTRODUCTION}

Predictive microbiology is an interdisciplinary area defined as: "the quantitative description of the microbial response in various ecosystems by employing mathematical models". A model is the description of a system or phenomenon that accounts for its known or inferred properties and might be used to further study its characteristics. Usually, predictive models have been built using raw data obtained from a pure culture in microbiological media. The composition and characteristics (broth, solid or semi-solid) of the medium are important factors that affect the behavior of microorganisms in foods. Mathematical models are developed to describe the effect of environmental conditions on microbial growth, thus allowing accurate predictions of microbial behaviors (Ding et al., 2011). Furthermore, the models can be valuable for estimating shifts in microbial concentrations (Fakrudding et al., 2011; Lee et al., 2014). In the area of predictive microbiology, there are primary and secondary models: (i) primary models describe a microbial response as a function of time for a single set of environmental conditions; and, (ii) secondary models quantify the effect of environmental variations on primary model parameters (Whiting, 1995).

Essentially, the function of a primary model is to obtain the growth or inhibition parameters of the microorganisms for each of the treatments established in the experimental design, whereas secondary models are built with parameters estimated from primary models. They are also employed to predict the response of microorganisms against new combinations of the environmental factors included in the experimental design. Once the secondary model has been constructed, it is necessary to corroborate the accuracy of its predictions. Statistical indices such as root mean square error (RMSE), bias (Bf) and accuracy factors (Af) have been proposed for estimating the accuracy of the model (Geitenes et al., 2013; Slongo et al., 2009). However, most of the predictive models have been developed on different food matrices (AntunesRohling et al., 2019; Schlei et al., 2020). Little research has been focused on modeling microbial growth in wastewater. The benefit of creating a secondary model relies on the ability to predict and optimize the duration of the sewage treatment processes.

The food industry has an elevated incidence of environmental contamination, for example, dairy industries produce large quantities of wastewater (Porwal et al., 2015). These wastes are impurities discharged into the environment without any previous decontamination treatment (Liu et al., 2015; Kumari et al., 2017); which significantly impacts public health and environmental sustainability. Hence, dairy waste requires decontamination treatments before it is discharged into sewer systems (Kumari et al., 2017). The principal substances in wastewater are oils, fats and long-chain fatty acids, which are contaminants of aquatic ecosystems (BecerraGutiérrez et al., 2015). Biological treatments have been employed as an alternative to decontaminate wastewater (González et al., 2012; Tarón-Dunoyer et al., 2020). Some yeasts are well-known for their ability to grow and decompose post-industrial wastes. Yarrowia lipolytica has been used as a biological agent for biodegradation of pollutant substrates. Additionally, this yeast is recognized as GRAS (Generally Recognized As Safe) in several industrial processes (Groenewald et al., 2014). This non-pathogenic, aerobic and dimorphic fungus has been studied in biodegradation processes and can be used for multiple biotechnological applications related to the production of enzymes and other compounds of 
industrial interest (da Costa et al., 2020). Nowadays, no investigations have been conducted pertaining to the modeling of $Y$. lipolytica in dairy waste. Thus, this work focuses on the development of a secondary model for predicting the growth of $Y$. lipolytica ATCC 9773 in wastewater.

\section{MATERIALS AND METHODS}

\subsection{Biological material}

Yarrowia lipolytica strain (ATCC 9773) was obtained from Medimark (C) Europe, 38033 Grenoble Cedex 2 - France.

\subsection{Preparation of the inoculum and obtaining the crude enzymatic extract (CEE)}

The activation of $Y$. lipolytica was carried out through incubation at $25^{\circ} \mathrm{C}$ in Petri dishes with PDA (potato dextrose agar) agar and olive oil as a lipid source for three days. Then, $Y$. lipolytica was suspended in a saline solution $(0.9 \% \mathrm{w} / \mathrm{v})$ until reaching $6 \times 10^{8} \mathrm{CFU} / \mathrm{mL}$ and then stored at $4^{\circ} \mathrm{C}$ until use. The dairy wastewater (DWW) was collected from a dairy industry located in Valledupar (Colombia) following the protocol mentioned by Taron-Dunoyer et al. (2020). Then, DWW volume (3 L) was divided into three subsamples with $\mathrm{pH}$ values of each subsample adjusted to 5.0; 6.5 and 8.0, respectively. It is important to note that $\mathrm{pH}$ was controlled by addition of acid $\left(1 \mathrm{~N} \mathrm{H}_{2} \mathrm{SO}_{4}\right)$ or base $(1 \mathrm{~N} \mathrm{KOH})$ taking into account $\mathrm{pH}$-metro readings, which were taken every 10 minutes. In order to obtain each growth curve, each subsample was added to an inoculum of $Y$. lipolytica $\left(6 \times 10^{8} \mathrm{CFU} / \mathrm{mL}\right)$. Likewise, $200 \mathrm{~mL}$ of a synthetic wastewater (SW) based on saltwater $(30 \% \mathrm{SW})$, sodium chloride (5.0\%), yeast extract $(0.5 \%)$, olive oil (1.0\%) and Triton X-100 (0.1\%) (Taron-Dunoyer et al., 2020) was inoculated with a similar amount of $Y$. lipolytica. The subsamples were aerated with filtered air at $2 \mathrm{~L} / \mathrm{min}$ and stirred at $300 \mathrm{rpm}$. Approximately every 20 minutes after inoculation, $1 \mathrm{~mL}$ was taken from each subsample and SW to carry out appropriate dilutions in peptone water and plated onto PDA agar. The petri dishes were incubated at $25^{\circ} \mathrm{C}$ for three days and then colonies were counted to obtain viable cell numbers $(\mathrm{CFU} / \mathrm{mL})$. Experiments lasted between 40 and $50 \mathrm{hrs}$.

\subsection{Primary modeling}

Growth curves of $Y$. lipolytica were constructed by plotting the logarithm of the number of microorganisms versus time at the different $\mathrm{pH}$ investigated. Each point of the growth curve corresponds to the average value of the entire set of samples assessed (at least three replicates of each was used to allow for statistical analysis). For growth curve fitting, the Buchanan model (Huang, 2013) was used to encounter the optimum fit for the growth curve (Equations 1 and 2).

$$
\begin{aligned}
& {\left[Y(t)=y_{0}+y_{\max }-\operatorname{In}\left\{e^{y_{0}}+\left[e^{y_{\max }}-e^{y_{0}}\right] e^{-\mu \max B(t)}\right\}\right]} \\
& {\left[B(t)=t+\frac{1}{\alpha} \operatorname{In} \frac{1+e^{-\alpha(t-\lambda)}}{1+e^{\alpha \lambda}}\right]}
\end{aligned}
$$

Where $y_{0}, y_{\max }$ and $y_{(t)}$ are the bacterial concentration in natural logarithm at initial, maximum, at time $t ; \mu_{\max }$ represents the maximum growth rate $[(\log \mathrm{CFU} / \mathrm{g}) / \mathrm{h}]$, and $\lambda$ represents the latency phase. The latency phase coefficient is $\alpha 4$.

\subsection{Secondary modeling}

The secondary model establishes a linear relationship between the natural logarithm $(\mathrm{Ln})$ of $\mu_{\max }$ and $\mathrm{pH}$ (Equation 3).

$$
\operatorname{Ln}(x)=m x+b
$$

Where, $\mathrm{x}$ is the growth rate, $\mathrm{m}$ is the slope and $\mathrm{b}$ is the $\mathrm{y}$-intercept. 


\subsection{Validation of the secondary model}

The bias factor (Bf), accuracy factor (Af), and root mean square error (RMSE) were employed to evaluate the performance of the generated secondary model (Ross, 1996). The Equations for 4,5 and 6 are the following:

$$
\begin{aligned}
& {\left[A_{f}=10^{\left(\left.\sum\right|^{\log \mu \text { pred }} / \log \mu \text { obs } \mid / n\right)}\right]} \\
& {\left[B f=10^{\left(\sum \log \left(\frac{\text { pobs }}{\mu \text { pred }}\right) / n\right)}\right]} \\
& {\left[R M S E=\frac{\sum(\text { obs }- \text { pred })^{2}}{n}\right]}
\end{aligned}
$$

Where, the variable factors obs, pred, and $\mathrm{n}$ are the observed value, predicted value, and repetition number of the observed data, respectively.

\subsection{Statistical analysis}

The results for growth parameters of $Y$. lipolytica were expressed as means \pm standard deviation. The influence of $\mathrm{pH}$ levels on maximum specific growth rate $\left(\mu_{\max }\right)$ was evaluated through an analysis of variance (ANOVA one way); whereas, post hoc tests (LSD test) were used to determine statistical differences $(\mathrm{P}<0.05)$ using SPSS software version 23.0 for windows. It is important to note that all tests were repeated at least three times to allow for statistical evaluation.

\section{RESULTS AND DISCUSSION}

Growth curves of Yarrowia lipolytica investigated in DWW at different $\mathrm{pH}$ levels $(5,6.5$ and 8.0) were obtained as described in the Materials and Methods section. The growth curves of Y. lipolytica ATCC 9773 were fitted using the Buchanan model and kinetic parameters were obtained. Figure 1 depicts the growth phases (lag, exponential and stationary phase) of $Y$. lipolytica in DWW. Similar behavior was observed for $Y$. lipolytica in SW (data not shown). These findings show the capability of Y. lipolytica of using some compounds present in the wastewater as a source of carbon, nitrogen and energy. Y. lipolytica is a non-conventional yeast due to its diverse biosynthetic potential (Egermeier et al., 2017). Dairy residues are considered highly biodegradable due to Y. lipolytica's ability to reduce BOD5 and COD to $43.32 \%$ and $44.30 \%$, respectively (Taron-Dunoyer et al., 2020). Hence, it could be an interesting model to predict the growth of $Y$. lipolytica in wastewater.

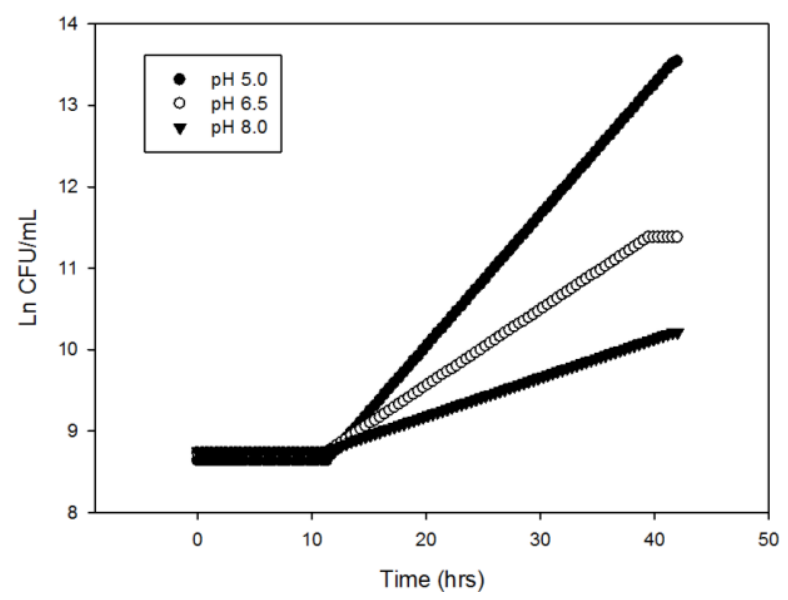

Figure 1. Effect of $\mathrm{pH}$ on growth of Yarrowia lipolytica in dairy wastewater. 
The suitability of primary models employed for developing predictive models is based on two factors: (i) environmental conditions and (ii) the microorganisms involved (Yoon, 2010). In the current study, Buchanan's primary predictive model was applied to model the growth of $Y$. lipolytica in a biodegradation treatment. Fitting the growth curves to the Buchanan model allows for determining growth parameters such as initial count cells $\left(\mathrm{Y}_{0}\right)$, maximum growth rate $(\mu)$, latency phase $(\lambda)$ and maximum cell population $\left(Y_{\max }\right)$ as illustrated Table 1.

Table 1. Growth parameters of $Y$. lipolytica at different $\mathrm{pH}$ values using the Buchanan model.

\begin{tabular}{clcc}
\hline $\mathrm{pH}$ levels & Parameters & Y. lipolytica $(\mathrm{DWW})$ & Y. lipolytica $(\mathrm{SW})$ \\
\hline \multirow{4}{*}{5.0} & $\mathrm{Y}_{0}(\log \mathrm{CFU})$ & $8.630^{\mathrm{a}}$ & $8.820^{\mathrm{a}}$ \\
& $\lambda(\mathrm{h})$ & $8.635^{\mathrm{a}}$ & $9.985^{\mathrm{b}}$ \\
& $\mathrm{Y}_{\max }(\log \mathrm{CFU})$ & $14.020^{\mathrm{a}}$ & $13.540^{\mathrm{a}}$ \\
& $\mu\left(\mathrm{h}^{-1}\right)$ & $0.168^{\mathrm{a}}$ & $0.161^{\mathrm{a}}$ \\
\hline \multirow{4}{*}{6.5} & $\mathrm{Y}_{0}(\log \mathrm{CFU})$ & $8.930^{\mathrm{a}}$ & $8.630^{\mathrm{a}}$ \\
& $\lambda(\mathrm{h})$ & $11.163^{\mathrm{a}}$ & $10.711^{\mathrm{a}}$ \\
& $\mathrm{Y}_{\max }(\log \mathrm{CFU})$ & $12.000^{\mathrm{a}}$ & $11.380^{\mathrm{b}}$ \\
& $\mu\left(\mathrm{h}^{-1}\right)$ & $0.129^{\mathrm{a}}$ & $0.094^{\mathrm{b}}$ \\
\hline \multirow{4}{*}{8.0} & $\mathrm{Y}_{0}(\log \mathrm{CFU})$ & $8.745^{\mathrm{a}}$ & $8.790^{\mathrm{a}}$ \\
& $\lambda(\mathrm{h})$ & $11.325^{\mathrm{a}}$ & $14.302^{\mathrm{b}}$ \\
& $\mathrm{Y}_{\max }(\log \mathrm{CFU})$ & $11.340^{\mathrm{a}}$ & $10.210^{\mathrm{b}}$ \\
& $\mu\left(\mathrm{h}^{-1}\right)$ & $0.094^{\mathrm{a}}$ & $0.048^{\mathrm{b}}$ \\
\hline
\end{tabular}

Rows with no common letter showed statistically significant difference (significance level<0.05).

$\mathrm{Y}_{0}$ values were not modified significantly $(\mathrm{P}>0.05)$ by the substrate (DWW and $\mathrm{SW}$ ) or its pH level. $\mathrm{Y}_{0}$ had values between 8.630 and $8.930 \log \mathrm{CFU}$ indicating that $\mathrm{Y}_{0}$ can be controlled at the beginning of the biodegradation process, that is when the microorganisms are incorporated into the sewage treatment system. $\lambda$, represents the time that microorganisms take to adapt to new environmental or nutritional conditions (Swinnen et al., 2004). This variable showed a tendency to increase with increasing $\mathrm{pH}$ of the substrates (DWW and SW) from 5.0 to 8.0. The highest values were found in SW at different $\mathrm{pH}$ levels: at $\mathrm{pH} 8.0-\lambda-14.302 \mathrm{~h}$; at $\mathrm{pH} 6.5-\lambda-10.711 \mathrm{~h}$ and at $\mathrm{pH} 5.0-\lambda-9.985 \mathrm{~h}$. This result suggests that the $\lambda$ parameter was directly proportional to $\mathrm{pH}$ levels. Similar results were obtained with $Y$. lipolytica in DWW; where, the highest value $(11.325 \mathrm{~h})$ was obtained at $\mathrm{pH}$ of 8.0 , while the lowest value, $8.635 \mathrm{~h}$, was obtained at $\mathrm{pH}$ of 5.0. $\mathrm{Y}_{\max }$ is another parameter calculated by the Buchanan model, which corresponds to the maximum microbial concentration reached at the end of the exponential phase. In DWW, the highest $\mathrm{Y}_{\max }$ value (14.020 $\log \mathrm{CFU}$ ) was reached at $\mathrm{pH} 5.0$ followed by pH 6.5 and 8.0 with 12.000 and $11.340 \log$ CFU, respectively. On the other hand, in regard to $\mathrm{SW}$, the highest value was obtained at $\mathrm{pH}$ of 5.0 (13.540 $\log \mathrm{CFU})$, while the lowest value was reached at $\mathrm{pH} 8.0$ (10.210 $\log \mathrm{CFU})$. Generally, the $\mathrm{Y}_{\max }$ values were higher in DWW than SW indicating that DWW is a good substrate to support $Y$. lipolytica growth and it could be used for biotechnological applications.

$\mu_{\max }$ is a key parameter because it represents the growth rate of microorganisms. Although it must be highlighted that $\mu_{\max }$ values mainly depend on the environmental conditions (ArroyoLópez et al., 2012). This parameter was inversely proportional to the $\mathrm{pH}$ levels. The lowest values were obtained at $\mathrm{pH} 8.0$ for both DWW and SW corresponding to 0.094 and $0.048\left(\mathrm{~h}^{-1}\right)$, respectively. Similar findings were published by da Costa et al. (2020), who cultivated $Y$. lipolytica in yeast peptone media at $29^{\circ} \mathrm{C}$, calculating values of $\mu$ close to $0.1114 \mathrm{~h}^{-1}$. Skandamis and Jeanson (2015) mentioned that $\mu$ reduction is caused mainly by limitations of nutrients, oxygen and production of some metabolites. 


\subsection{Secondary modeling}

The $\mu_{\max }$ values calculated by applying the Buchanan model were employed to develop the secondary model using a linear equation. Besides $\mu_{\max }$ was significantly affected by $\mathrm{pH}$ values and type of substrate. The secondary model describes the effect of $\mathrm{pH}$ on $Y$. lipolytica behavior in a biodegradation process. The changes in $\mu$ of $Y$. lipolytica, according to $\mathrm{pH}$ levels, is illustrated in Figure 2. Where, a reduction in $\mu$ values is observed when $\mathrm{pH}$ increases.

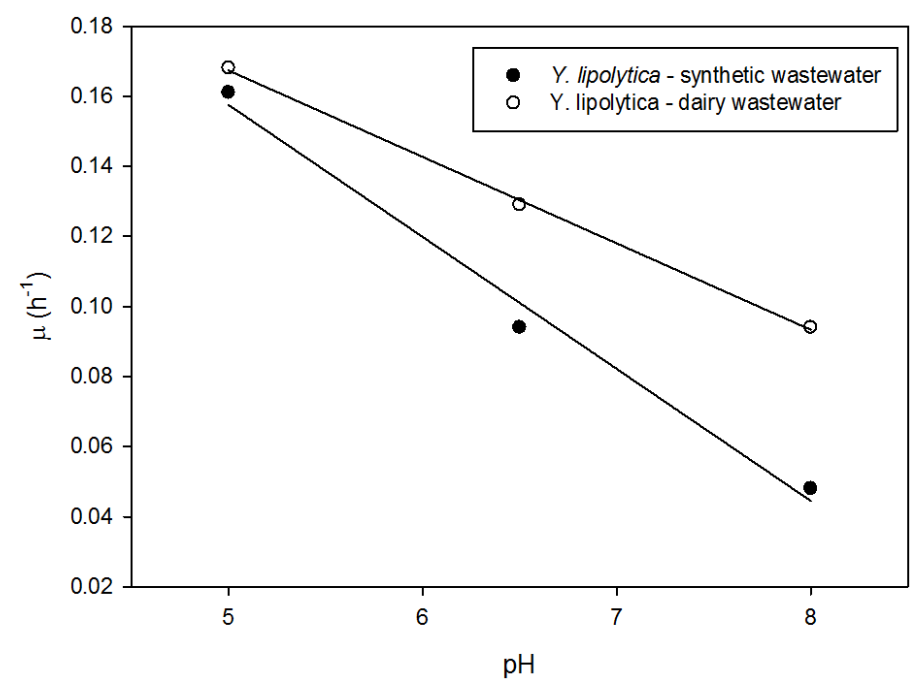

Figure 2. Effect of $\mathrm{pH}$ on maximum growth rates of Yarrowia lipolytica.

Considering that most of the secondary models are developed under real and abusive environmental conditions, a validation process must be carried out in order to verify the predictive accuracy of the models. Therefore, statistical indices such as accuracy (Af) and bias (Bf) have been suggested for validating secondary models (Baranyi et al., 1999; López et al., 2006).

Af is the sum of absolute differences between observed and predicted values of one parameter calculated in the secondary model. Bf represents the relative deviation among observed and predicted; moreover, this parameter allows for determining whether the model over or under-predicts microbial growth (Dalgaard and Jorgensen, 1998). For instance, a Bf value outside the range 0.7 to 1.5 indicates that the model is unsuitable (Choi et al., 2019; Ross, 1996; 1999). A perfect agreement between predictions and observations must have values of Af and Bf equal to 1.0 (Choi et al., 2019; Ross, 1999). Another parameter in a validation process is RSME, which compares observed values in the experiment with those calculated by the predictive model. A good validation process has values of RSME close to zero (Baranyi et al., 1996). The mathematical validation of $Y$. lipolytica growth is summarized in Table 2; where values of $\mathrm{Af}$ and $\mathrm{Bf}$ close to 1 were obtained based on secondary models. This indicates that both linear models developed herein can optimally simulate $Y$. lipolytica's growth in both dairy wastewater and synthetic wastewater at different $\mathrm{pH}$ levels (5.0 to 8.0). Regarding RSME, low values were achieved, corroborating that lineal models were suitable for predicting $Y$. lipolytica's growth in a sewage treatment.

Table 2. Mathematical validation of the secondary model to describe the behavior of $Y$. lipolytica

\begin{tabular}{lccc}
\hline Equation & Af & Bf & RSME \\
\hline In $(\mu)=-0.0247 x+0.2907(D W W)$ & 1.001 & 0.998 & 0.001 \\
In $(\mu)=-0.0377 x+0.3458(C W)$ & 1.009 & 0.990 & 0.006 \\
\hline
\end{tabular}


It is important to emphasize that real wastewater was used to develop a secondary model to predict Yarrowia lipolytica's growth. Interestingly, when microbial growth is carried out in artificial microbiological culture, models usually overestimate the predictions (Pérez and Valero, 2013). Hence, the models constructed herein could be considered consistent for practical use and improve the sewage treatment processes.

\section{CONCLUSIONS}

In the present article, a secondary model was developed to simulate the growth of Yarrowia lipolytica in both dairy wastewater (DWW) and synthetic wastewater at different $\mathrm{pH}$ levels. This model established a linear relationship between $\mu_{\max }$ and $\mathrm{pH}$. The validation process yielded accuracy and bias factors of approximately 1; while values of RSME were low. These results indicate that the secondary model developed can predict $Y$. lipolytica growth in wastewater; hence proving highly valuable for optimizing sewage treatment processes that include this kind of microorganism. Furthermore, DWW proved to be a good substrate to support the growth of Yarrowia lipolytica and could be used for biotechnological approaches such as the production of enzymes.

\section{REFERENCES}

ANTUNES-ROHLING, A.; ARTAIZ, A.; CALERO, S.; HALAIHEL, N.; GUILLÉN, S.; RASO, J.; ÁLVAREZ, I.; CEBRIÁN, G. Modelling microbial growth in modifiedatmosphere-packed hake (Merluccius merluccius) fillets stored at different temperatures. Food Research International, v. 122, n. 1, p. 506-516, 2019. https://doi.org/10.1016/j.foodres.2019.05.018

ARROYO-LÓPEZ, F.; BAUTISTA-GALLEGO, J.; GARRIDO-FERNANDEZ, A. Role of Predictive Microbiology in Food Preservation. In: BHAT, R.; ALIAS, A. K.; PALIYATH, G. Progress in Food Preservation. New York: John Wiley \& Sons, 2012. p. 389-404.

BARANYI, J.; ROSS, T.; MCMEEKIN, T. A.; ROBERTS, T. A. Effects of parameterization on the performance of empirical models used in "predictive microbiology". Food Microbiology, v. 13, n. 1, p. 83-91, 1996. https://doi.org/10.1006/fmic.1996.0011

BARANYI, J.; PIN, C.; ROSS, T. Validating and comparing predictive models. International Journal of Food Microbiology, v. 48, n. 1. p. 159-166, 1999. https://dx.doi.org/10.1016/s0168-1605(99)00035-5

BECERRA-GUTIÉRREZ, L. K.; HORNA-ACEVEDO, M. V.; BARRIONUEVO-ALBÚJAR, K. I. Influence of native microorganisms in treatment of slaughterhouses waste water. Revista del Cuerpo Médico del Hospital Nacional Almanzor Aguinada Asenjo, v. 8, n. 1, p. 15-18, 2015. https://doi.org/10.35434/rcmhnaaa.2015.81.231

CHOI, W. S.; SON, N.; CHO, J. I.; JOO, I. S.; HAN, J. A.; KWAK, H. S.; SUH, S. H. Predictive model of Staphylococcus aureus growth on egg products. Food Science and Biotechnology, v. 28, n. 1, p. 913-922, 2019.

DALGAARD, P.; JORGENSEN L. Predicted and observed growth of Listeria monocytogenes in seafood challenge tests and in naturally contaminated cold smoked salmon. International Journal of Food Microbiology, v. 40, n. 1, p. 105-115, 1998. https://dx.doi.org/10.1016/s0168-1605(98)00019-1 
DA COSTA, A. M.; DE OLIVEIRA LOPES, V. R.; VIDAL, L.; NICAUD, J. M.; DE CASTRO, A. M.; ZARUR, M. A. Poly (ethylene terephthalate) (PET) degradation by Yarrowia lipolytica: Investigations on cell growth, enzyme production and monomers consumption. Process Biochemistry, v. 95, n. 1, p. 81-90, 2020. https://doi.org/10.1016/j.procbio.2020.04.001

DING, T.; SHIM, Y. H.; KIM, H. N.; HA, S. D.; CHUNG, M. S.; HWANG, I. G.; OH, D.H Development of predictive model for the growth of Staphylococcus aureus in Kimbab. Food Science and Biotechnology, v. 20, n. 1, p. 471-476, 2011. https://doi.org/10.1007/s10068-011-0065-y

EGERMEIER, M.; RUSSMAYER, H.; SAUER, M.; MARX, H. Metabolic flexibility of Yarrowia lipolytica growing on glycerol. Frontiers in Microbiology, v. 8, n. 1, p. 1-9, 2017. https://doi.org/10.3389/fmicb.2017.00049

FAKRUDDIN, M.; MAZUMDER, R. M.; MANNAN, K. Predictive microbiology: Modeling microbial responses in food. Ceylon Journal of Science, v. 40, n. 1, p. 121-131, 2011.

GEITENES, S.; OLIVEIRA, M. F. B.; KALSCHNE, D. L.; SARMENTO, C. M. P. Modelagem do crescimento de bactérias láticas e análise microbiológica em apresuntado e presunto cozido fatiados e embalados à vácuo. Revista Ciências Exatas e Naturais, v. 15, n. 1, p. 113-133, 2013.

GONZÁLEZ, D.; AMAÍZ, L.; MEDINA, L.; VARGAS, R.; IZZEDDIN, N.; VALBUENA, O. Biodegradación de residuo graso industrial empleando bacterias endógenas. Revista Latinoamericana de Biotecnologia Ambiental y Algal, v. 3, n. 2, p. 105-118, 2012.

GROENEWALD, M.; BOEKHOUT, T.; NEUVÉGLISE, C.; GAILLARDIN, C.; VAN DIJCK, P. W. M.; WYSS, M. Yarrowia lipolytica: safety assessment of an oleaginous yeast with a great industrial potential. Critical Reviews in Microbiology, v. 40, n. 3, p. 187-206, 2014. https://dx.doi.org/10.3109/1040841X.2013.770386

HUANG, L. H. IPMP-A comprehensive data analysis tool of predictive microbiology. International Journal of Food Microbiology, v. 171, n. 1, p. 100-107, 2013. https://doi.org/10.1016/j.ijfoodmicro.2013.11.019

KUMARI, A.; RAZI, A.; NEGI, S.; KHARE, S. Biodegradation of waste grease by Penicillium chrysogenum for production of fatty acid. Bioresource Technology, v. 226, p. 31-38, 2017. https://doi.org/10.1016/j.biortech.2016.12.006

LEE, Y. J.; JUNG, B. S.; YOON, H. J.; KIM, K. T.; PAIK, H. D.; LEE, J. Y. Predictive model for the growth kinetics of Listeria monocytogenes in raw pork meat as a function of

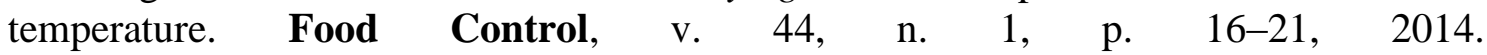
https://doi.org/10.1016/j.foodcont.2014.03.024

LIU, Y.; KANG, X.; LI, X. L.; YUAN, Y. Performance of aerobic granular sludge in a sequencing batch bioreactor for slaughterhouse wastewater treatment. Bioresource technology, v. 190, p. 487-491, 2015. https://doi.org/10.1016/j.biortech.2015.03.008

LÓPEZ, F. N.; QUINTANA, M. C.; FERNÁNDEZ, A. G. The use of a D-optimal design to model the effects of temperature, $\mathrm{NaCl}$, type and acid concentration on Lactobacillus pentosus IGLAC01. Journal of Applied Microbiology, v. 101, n. 1, p. 913-926, 2006. https://dx.doi.org/10.1111/j.1365-2672.2006.02979.x 
PÉREZ, F.; VALERO, A. Predictive microbiology in foods. Heidelberg: Springer, 2013.

PORWAL, H. J.; MANE, A. V.; VELHAL, S. Biodegradation of Dairy Effluent by Using Microbial Isolates Obtained from activated sludge. Water Resources and Industry, v. 9, p. 1-15, 2015. https://doi.org/10.1016/j.wri.2014.11.002

ROSS, T. Indices for performance evaluation of predictive models in food microbiology. Journal of Applied Bacteriology, v. 81, n. 1, p. 501-508, 1996. https://doi.org/10.1111/j.1365-2672.1996.tb03539.x

ROSS, T. Predictive food microbiology models in the meat industry. Sydney: Meat and livestock Australia, 1999. p. 196.

SCHLEI, K.; ANGIOLETTI, B.; FERNANDES DE CARVALHO, L.; BERTOLI, S.; REITER, M.; KREBS DE SOUZA, C. Influence of temperature on microbial growth during processing of kochkase cheese made from raw and pasteurised milk. International Dairy Journal, v. 109, n. 1, p. 1-7, 2020. https://doi.org/10.1016/j.idairyj.2020.104786

SKANDAMIS, P. N.; JEANSON, S. Colonial vs. planktonic type of growth: mathematical modelling of microbial dynamics on surfaces and in liquid, semiliquid and solid foods. Frontiers of Microbiology, v. 6, n. 1, 2015. https://doi.org/10.3389/fmicb.2015.01178

SLONGO, A. P.; ROSENTHAL, A.; CAMARGO, L. M. Q.; DELIZA, R.; MATHIAS, S. P.; ARAGÃO, G. M. F. Modeling the growth of lactic acid bacteria in sliced ham processed by high hydrostatic pressure. LWT - Food Science and Technology, v. 42, n. 1, p. 303-306, 2009. https://doi.org/10.1016/j.lwt.2008.06.010

SWINNEN, I. A.; BERNAERTS, K.; DENS, E. J.; GEERAERD, A. H.; VAN IMPE, J. F. Predictive modelling of the microbial lag phase: a review. International Journal of $\begin{array}{llllllll}\text { Food Microbiology, } & \text { v. 94, n. } 2004 .\end{array}$ https://doi.org/10.1016/j.ijfoodmicro.2004.01.006

TARÓN-DUNOYER， A.; GONZÁLEZ-CUELLO， R. E.; PEREZ-SALINAS, R. Biodegradation of dairy wastes using crude enzymatic extract of Yarrowia lipolytica ATCC 9773. Revista Ambiente \& Água, v. 15, n. 1, p. 1-9, 2020. https://dx.doi.org/10.4136/1980-993X

WHITING, R. C. Microbial modeling in foods. Critical Reviews in Food Science and Nutrition, v. 35, n. 1, p. 467-494, 1995. https://doi.org/10.1080/10408399509527711

YOON, Y. H. Principal theory and application of predictive microbiology. Food Science and Industry, v. 43, n. 1, p. 70-74, 2010. 